\title{
Analisis Perubahan Garis Pantai Kabupaten Jembrana dengan Menggunakan Citra Satelit Landsat 8
}

\author{
Mega Fitria Istiqomah ${ }^{1, \dagger}$, Sutrisno $^{1}$, Adi Wijaya ${ }^{2}$ \\ ${ }^{1}$ Program Studi Fisika, Fakultas Sains dan Teknologi, Universitas Islam Negeri Syarif Hidayatullah \\ Jakarta \\ ${ }^{2}$ Peneliti, Balai Penelitian dan Observasi Laut Bali, Kelompok Peneliti Ocean Remote Sensing, Jl. Baru \\ Perancak, Kecamatan Negara, Bali \\ †corresponding author : megafitriaist@gmail.com
}

\begin{abstract}
Abstrak. Kabupaten Jembrana mempunyai posisi yang strategis secara geografis, sebagai pintu gerbang Bali bagian barat yang merupakan kunci pertukaran dan percampuran budaya serta penduduk. Daerah ini berbatasan langsung dengan Selat Bali sehingga mendapat pengaruh angin laut yang membangkitkan gelombang dan pasang surut. Tujuan dari penelitian ini adalah untuk menganalisis perubahan garis pantai menggunakan teknologi penginderaan jauh pesisir Kabupaten Jembrana tahun 2013 hingga 2016. Metode yang digunakan dalam penelitian ini adalah metode penginderaan jauh menggunakan citra satelit Landsat 8 dan metode survei lapangan untuk mengetahui kondisi yang sebenarnya. Hasil penelitian ini menunjukkan bahwa perubahan garis pantai tahun 2013 sampai 2014 mengalami abrasi sebesar 801.717 $\mathrm{m}^{2}$ dan akresi sebesar $1348.564 \mathrm{~m}^{2}$, tahun 2014 sampai 2015 mengalami abrasi sebesar $4921.561 \mathrm{~m}^{2}$ dan akresi sebesar $388.969 \mathrm{~m}^{2}$, terakhir di tahun 2015 sampai 2016 perubahan akibat abrasi terjadi sebesar $384.637 \mathrm{~m}^{2}$ dan akresi sebesar $4431.331 \mathrm{~m}^{2}$.
\end{abstract}

Kata kunci : Citra Landsat 8, Kabupaten Jembrana, Perubahan Garis Pantai.

Abstract. Jembrana district has a strategic position geographically, as the gateway to west Bali which is the key exchange and the mixing of culture as well as residents. This area is directly adjacent to the Strait of Bali so it gets the sea breeze effect that evokes the waves and tides. The purpose of this study was to analyze the changes in the shoreline using remote sensing technology at Jembrana coast in 2013 to 2016. The method used in this research is the method of remote sensing using Landsat 8 satellite imagery and field survey methods to determine the actual condition. These results indicate that changes in the coastline of 2013 to 2014 experience abrasion of $801717 \mathrm{~m}^{2}$ and accretion amounted to 1348,564 $\mathrm{m}^{2}, 2014$ to 2015 experience abrasion of 4921,561 $\mathrm{m}^{2}$ and accretion amounted to $388969 \mathrm{~m}^{2}$, the last in 2015 until 2016 the changes due abrasion occurs at $384637 \mathrm{~m}^{2}$ and accretion amounted to $4431,331 \mathrm{~m}^{2}$.

Keywords: Jembrana, Landsat 8, Shoreline Changes.

\section{PENDAHULUAN}

Indonesia merupakan negara dengan kota yang sebagian berada di daerah pantai. Banyaknya aktivitas yang dilakukan di daerah pantai menyebabkan persoalan, salah satunya penambahan dan pengurangan wilayah daratan atau terjadinya perubahan garis pantai. Kabupaten Jembrana mempunyai posisi yang strategis secara geografis, sebagai pintu gerbang Bali bagian barat yang merupakan kunci pertukaran dan percampuran budaya serta penduduk. Daerah ini berbatasan langsung dengan Selat Bali sehingga mendapat pengaruh angin laut yang membangkitkan gelombang dan pasang surut. Perubahan garis pantai dapat diketahui dengan metode penginderaan jauh melalui citra satelit. Data citra penginderaan jauh mencakup wilayah yang luas kemudian dianalisis dan diketahui daerah yang mengalami perubahan seperti abrasi dan akresi. Data citra satelit yang digunakan adalah data cita Satelit Landsat 8, merupakan seri satelit terbaru yang memiliki beberapa keunggulan terkait rentan panjang gelombang elektromagnetik yang ditangkap, sehingga tampilan citra lebih halus dan mengurangi terjadinya kesalahan interpretasi. 


\section{TINJAUAN PUSTAKA}

\section{Pantai}

Wilayah pinggir laut yang berbatasan langsung dengan wilayah daratan disebut sebagai pantai. Wilayah laut dan darat dibatasi oleh garis yang kemudian disebut garis pantai. Menurut Bambang Triatmodjo (1999), garis pantai adalah garis batas pertemuan antara daratan dan air laut, dimana posisinya tidak tetap dan dapat berpindah sesuai dengan pasang surut air laut dan erosi pantai yang terjadi.

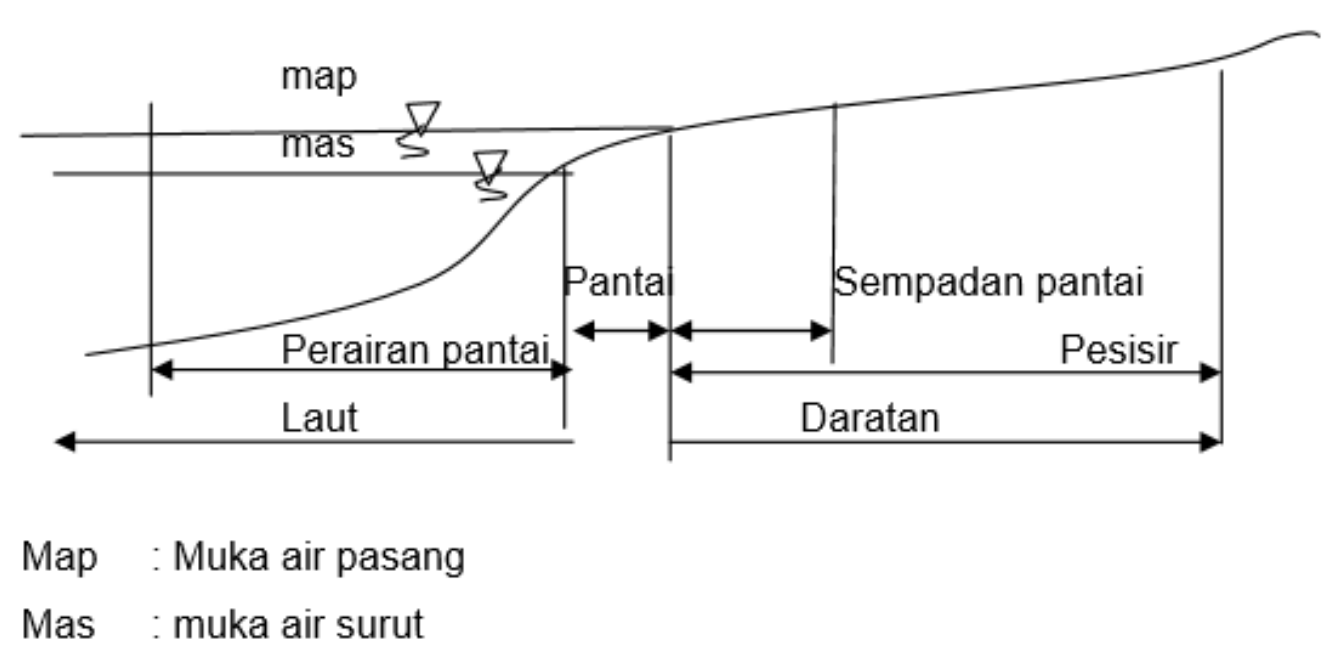

GAMBAR 1. Definisi dan Batasan Pantai. (Triatmodjo, 1999)

Menurut Wibisono (2005) pantai memiliki beberapa tipe, diantaranya pantai pasir, pantai pasir lumpur, pantai pasir karang, pantai karang dan pantai berbatu. Proses terjadinya pantai dipengaruhi oleh gelombang, angina, pasang surut, dan transportasi sedimen.

\section{Perubahan Garis Pantai}

Garis pantai tidak sama dengan garis pesisir (coastline). Pada saat air dalam kedudukan pasang tinggi, maka terbentuk garis yang disebut garis pesisir (coastline). Garis pesisir ini terjadi relatif tetap dan terletak pada tempat tertentu. Pada saat air berada pada kedudukan pasang tertinggi (highest water level) maka garis pantai dan garis pesisir berada pada kedudukan berimpitan (Fandeli, 2011). Kawasan pantai merupakan satu kawasan yang sangat dinamik terhadap perubahan, begitu pula dengan perubahan garis pantainya. Perubahan garis pantai adalah salah satu proses tanpa henti (terus-menerus) melalui berbagai proses alam di pantai yang meliputi pergerakan sedimen, arus susur pantai (longshore current) tindakan ombak dan penggunaan lahan. Hal lain yang mempengaruhi perubahan garis pantai antara lain: gelombang laut, angin laut, pasang surut, serta sedimentasi yang berdampak pada abrasi dan akresi.

\section{Penginderaan Jauh}

Menurut Lindgren dalam Susanto (1986) penginderaan jauh adalah teknik yang dikembangkan untuk peroleh dan analisis informasi tentang bumi, informasi tersebut berbentuk radiasi elektromagnetik yang dipantulkan atau dipancarkan dari permukaan bumi. Objek hasil perekaman yang dilakukan dengan penginderaan jauh ialah berupa susunan dari beberapa material. Pengaruhnya terhadap interaksi energi elektromagnetik, material tersebut memiliki karakteristik yang bervariasi. Energi tersebut dapat berupa gelombang elektromagnetik yang berasal dari pancaran satelit maupun melalui pancaran radiasi matahari. Karakteristik pantulan 
dari kenampakan objek di permukaan bumi dapat diukur sebagai fungsi panjang gelombang yang disebut pantulan spektral. Secara matematis dapat didefenisikan;

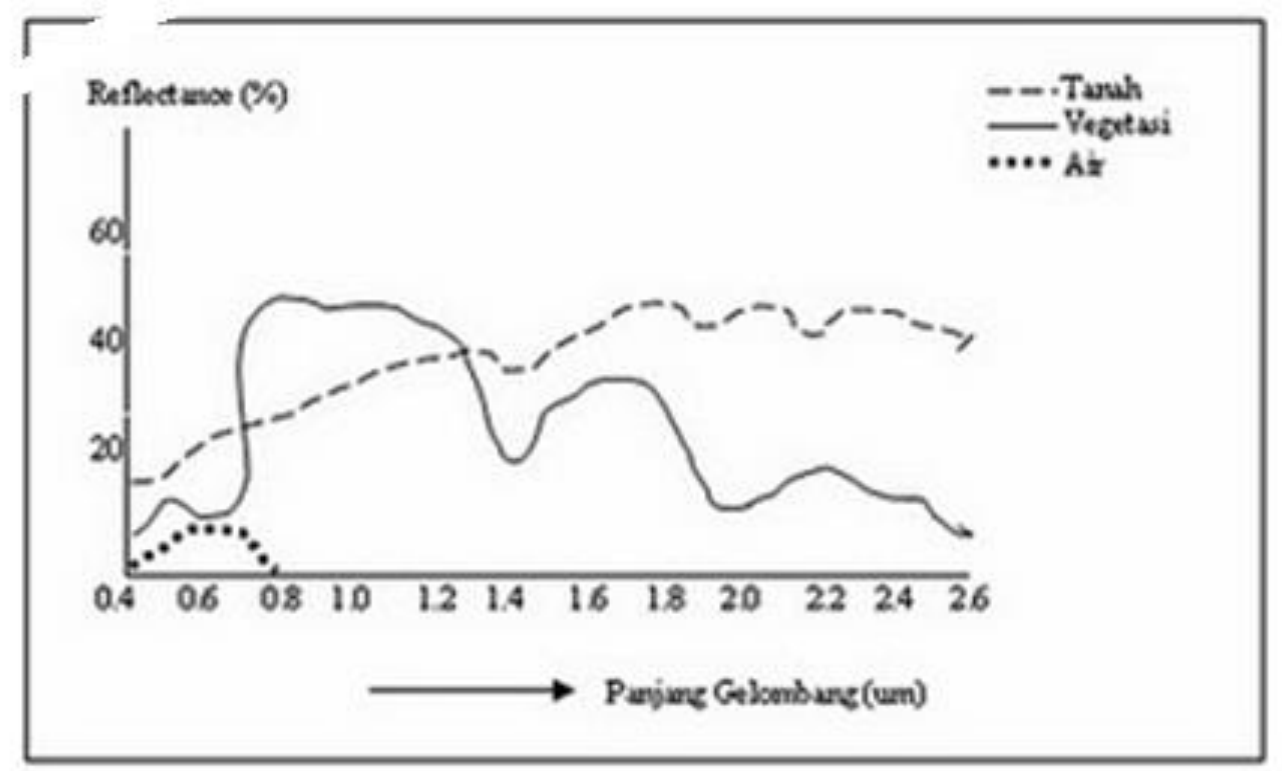

GAMBAR 2. Karakteristik spektral, reflektansi tanah, air dan vegetasi (Lillesand and Kiefer, 1987)

Dari gambar diatas, dapat dilihat peranan spektrum tampak mata (visible spectrum) untuk sumber daya kelautan, yang ditunjukkan oleh kurva reflectancenya pada tubuh air. Spektrum ini mempunyai panjang gelombang berkisar antara 0.4-0.7 um, yang terdiri dari spektrum tampak mata biru (visible blue) dengan panjang gelombang 0.4-0.5 um, spektrum tampak mata hijau (visible green) dengan panjang gelombang 0.5-0.6 um dan spektrum tampak mata merah (visible red) dengan panjang gelombang 0.6-0.7 um (Jensen, 1986; Lillesand and Kiefer, 1987; Swain and Davis, 1978).

\section{Satelit Landsat}

Landsat Data Continuity Mission (LDCM) atau dikenal juga dengan nama Landsat 8 merupakan satelit generasi terbaru dari Program Landsat. Satelit ini merupakan project gabungan antara USGS dan NASA beserta NASA Goddard Space Flight Center dan diluncurkan pada hari Senin, 11 Februari 2013 di Pangkalan Angkatan Udara Vandeberg, California - Amerika Serikat. Satelit Landsat 8 yang direncanakan mempunyai durasi misi selama 5 - 10 tahun ini, dilengkapi dua sensor yang merupakan hasil pengembangan dari sensor yang terdapat pada satelit-satelit pada Program Landsat sebelumnya. Kedua sensor tersebut yaitu Sensor Operational Land Manager (OLI) yang terdiri dari 9 band serta Sensor Thermal Infrared Sensors (TIRS) yang terdiri dari 2 band.

\section{METODELOGI PENELITIAN}

\section{Waktu dan Tempat Penelitian}

Penelitian ini dilaksanakan sejak 30 Januari hingga 10 Maret 2017. Lokasi penelitian dilakukan di Pesisir Kabupaten Jembrana Bali. Secara astronomis, Kabupaten Jembrana terletak

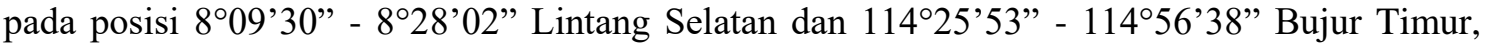
dengan Kabupaten Buleleng sebagai batas utara, Samudera Indonesia di sebelah selatan, Selat 
Bali di sebelah barat dan Kabupaten Tabanan di sebelah timur. Sedangkan lokasi pengolahan data dilakukan di Balai Penelitian dan Observasi Laut (BPOL) Bali.

Data

- Data citra Landsat 8 path/row 117/066, tahun 2013, 2014, 2015 dan 2016

- Peta administrasi Kabupaten Jembrana

- Data Pasang Surut Pantai Kabupaten Jembrana

\section{Peralatan Penelitian}

Peralatan yang digunakan melakukan penelitian terdiri dari laptop dengan software ArcGIS 10.1 dan ENVI 5.3 untuk pengolahan data, GPS (Global Positioning System) untuk mengetahui letak posisi objek, dan kamera untuk dokumentasi.

\section{Pengolahan Data}

Tahapan yang pertama yaitu pra pengolahan meliputi kalibrasi radiometrik, koreksi atmosfer dan menghilangkan awan pada citra. Kemudian melakukan klasifikasi unsupervised untuk membuat kelas antara darat dan laut. Tahap selanjutnya yaitu mengubah format data dari raster hingga menjadi shapefile. Lalu melakukan tumpang susun data tahun 2013, 2014, 2015 dan 2016 hingga memperoleh gambaran perubahan garis pantai.

Berdasarkan data tersebut kemudian melakukan verifikasi lapangan berdasarkan data administrasi desa yang ada di Kabupaten Jembrana. Tahap verifikasi meliputi wawancara, dokumentasi dan pencatatan waktu serta koordi nat lokasi.

\section{ANALISA DAN PEMBAHASAN}

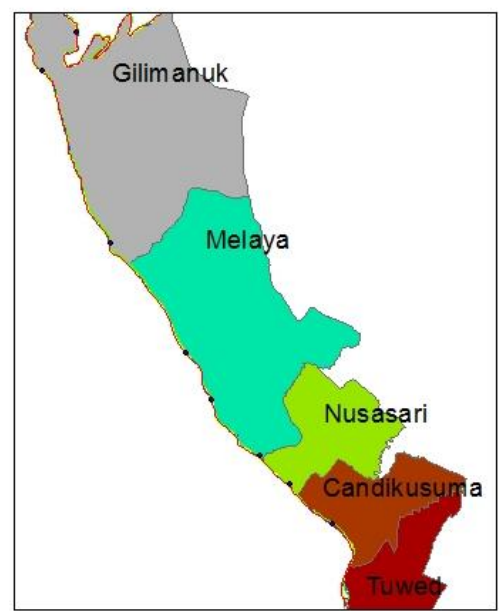

GAMBAR 3. Desa Pesisir di Kecamatan Melaya

Berdasarkan gambar di atas, Desa Gilimanuk mengalami perubahan yang tidak signifikan. Tahun 2013 ke 2014 di beberapa titik garis pantai lebih banyak mengalami kemunduran (abrasi). Dari wawancara yang dilakukan dengan Bapak Holidin (nelayan setempat), diperoleh informasi bahwa titik-titik pengambilan data lapangan tidak mengalami perubahan. Selanjutnya, pada Desa Melaya, garis pantai juga berubah secara dinamis. Garis pantai tahun 2015 terlihat cukup jauh mengalami kemunduran (abrasi). Berdasarkan informasi dari wawancara yang dilakukan dengan Bapak Nahiruddin (pengepul ikan) 4 tahun lalu jarak 
pantai kurang lebih 10 meter dari jarak pantai saat pengambilan data. Bapak Made Desa juga menyebutkan hal yang sama, jarak pantai dahulu (3 tahun lalu) $10 \mathrm{~m}$ dari jarak pantai saat ini. Di titik pengambilan data, terlihat ada tanaman di sepanjang pesisir.

Pada Desa Nusasari, garis pantai juga mengalami perubahan. Di tahun 2014 hingga 2015, garis pantai di desa ini mengalami kemunduran. Bapak Nyoman Adiyasa yang merupakan penduduk setempat, memberi informasi bahwa Desa Nusasari mengalami abrasi sekitar 15 meter dalam kurun waktu 5 tahun terakhir. Bahkan saat pasang purnama, air laut bisa mencapai pura yang ada di pesisir

Desa Candikusama memiliki pantai berpasir hitam. Abrasi yang terjadi cukup besar. Bapak Tauhid mengatakan garis pantai mengalami kemunduran sekitar 200 meter dalam kurun waktu 5 tahun. Di pesisir pantai, terlihat adanya bangunan villa, hal itu juga menjadi salah satu penyebab terjadinya abrasi di lokasi ini. Desa Tuwed merupakan salah satu desa di kecamatan Melaya yang berbatasan langsung dengan pantai. Namun, di desa ini cukup sulit menemukan jalur ke lokasi pantai. Berdasarkan olahan data citra garis pantai terlihat mengalami kemunduran di tahun 2014. Karena lokasi pantai yang jauh dari pemukiman serta jalan, jadi tidak ada warga yang dapat langsung diwawancarai.

\section{Kecamatan Negara}

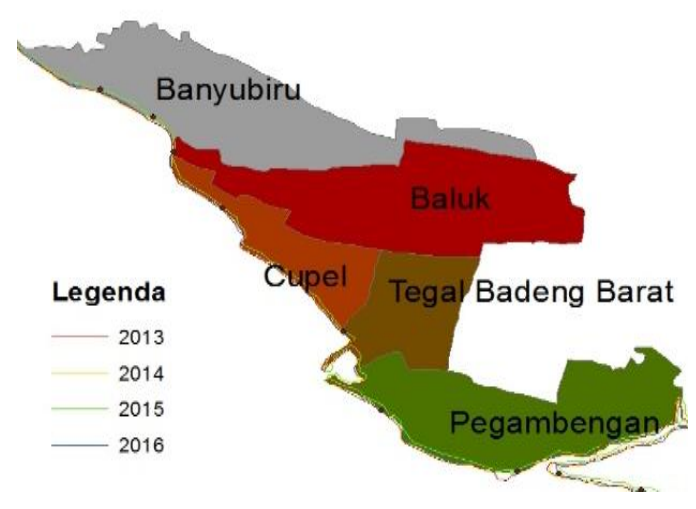

GAMBAR 4. Desa Pesisir di Kecamatan Negara.

Desa Banyubiru memiliki pantai yang cukup panjang. Sepanjang pesisir pantai terdapat tempat-tempat makan yang dibangun. Di desa ini juga terdapat pemukiman penduduk. Dari hasil wawancara dengan Bapak Basri (nelayan), diperoleh informasi bahwa garis pantai di lokasi ini mengalami abrasi sejauh 200 meter. Pengaruh gelombang tinggi serta arus yang tegak lurus terhadap pantai menjadi salah satu faktor penyebab terjadinya abrasi. Selain itu adanya bangunan-bangunan di sepanjang pesisir juga menjadi penyebab terjadinya perubahan garis pantai. Desa Baluk memiliki wilayah pantai yang cukup sempit. Tampilan hasil olahan citra, memperlihatkan, garis pantai di lokasi ini mengalami kemunduran (abrasi) tahun 2014 dan 2015. Pada pesisir pantai terdapat bangunan hotel, penginapan dan juga restaurant.

Desa Cupel memiliki wilayah pantai yang cukup luas. Menurut Bapak Sarani pantai Cupel mengalami abrasi sekitar 500 meter. Salah satu penyebab perubahan garis pantai di wilayah ini akibat adanya pembangunan pelabuhan pengambengan. Tahun 2013 hingga 2015 garis pantai mengalami kemunduran. di tahun 2016 garis pantai mengalami perubahan ke arah penambahan daratan. Desa Tegal Badeng Barat mengalami perubahan garis pantai berupa abrasi di tahun 2014. Faktor angin yang menyebabkan gelombang tinggi menjadi salah satu penyebabnya.

Selanjutnya, Desa Pengambengan adalah desa pesisir dengan mayoritas penduduknya berprofesi sebagai nelayan. Di desa ini pula dibangun pelabuhan penangkapan ikan. Akibat pembangunan pelabuhan, garis pantai di desa ini mengalami perubahan, yaitu penambahan daratan. 


\section{Kecamatan Jembrana}

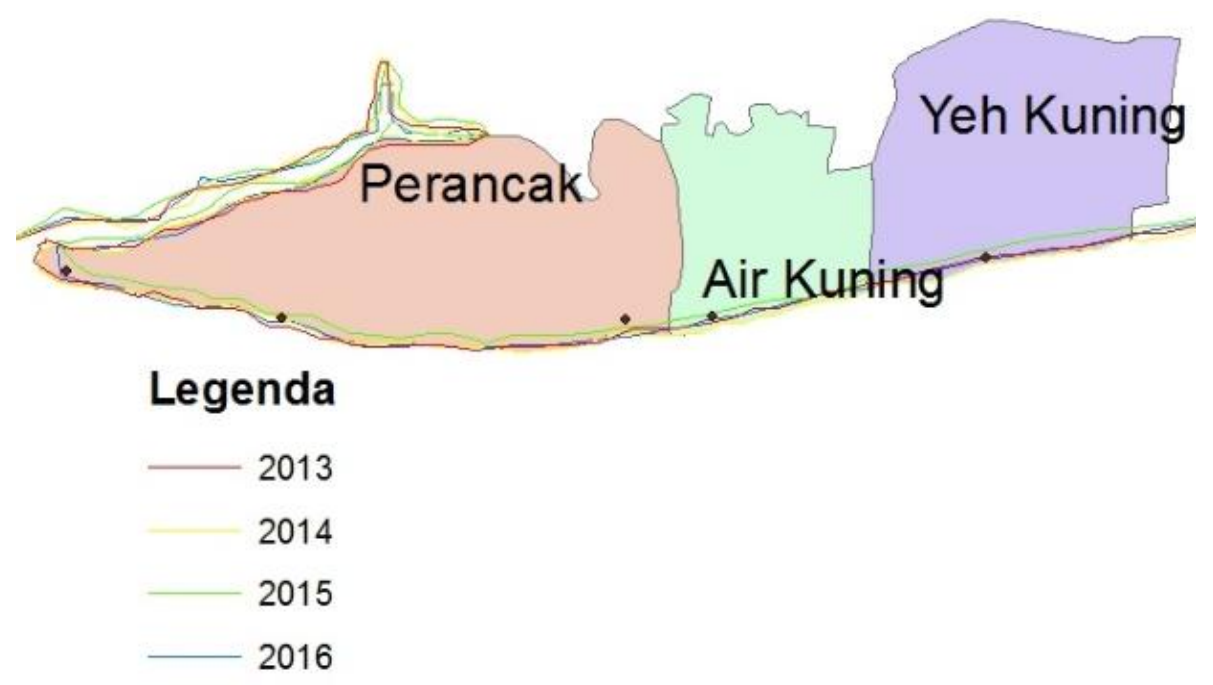

GAMBAR 5. Desa Pesisir di Kecamatan Jembrana.

Desa Perancak mengalami perubahan di sepanjang pantainya. Hasil olah citra, tahun 2014 di desa ini perubahan garis pantai akibat abrasi maupun akresi cenderung seimbang. Informasi dari Bapak Nengah Budiasa, di lokasi pengambilan data lapangan garis pantai tidak mengalami perubahan. Di desa ini juga terdapat hutan mangrove yang menghambat terjadinya abrasi. Pada Desa Air Kuning, perubahan garis pantai terjadi akibat abrasi. Bapak Sobari (nelayan) memberi informasi bahwa abrasi terjadi sekitar 200 meter selama 5 tahun terakhir. Air pasang saat purnama serta gelombang tinggi menjadi factor penyebab terjadinya perubahan garis pantai akibat abrasi. Desa Yeh Kuning merupakan desa dengan pantai wisata. Perubahan garis pantai yang terjadi di desa ini berdasarkan hasil olahan citra lebih banyak mengalami abrasi. Tahun 2014 hingga 2015 terlihat garis pantai mengalami kemunduran yang cukup jauh.

\section{Kecamatan Mendoyo}

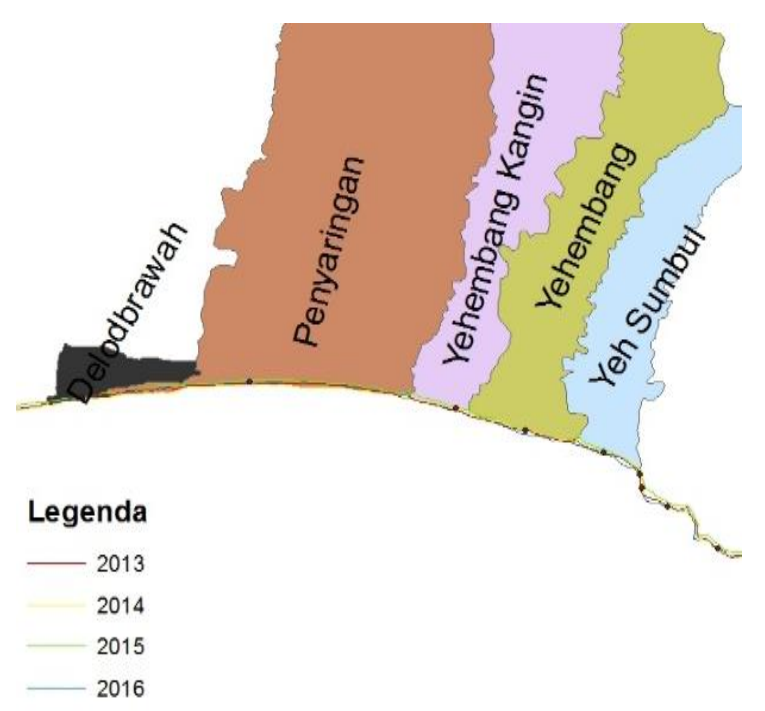

GAMBAR 6. Desa Pesisir di Kecamatan Mendoyo 
Desa Delodbrawah merupakan desar pesisir dengan pantai yang dimanfaatkan sebagai objek wisata. Di sekitar pantai terdapat tanaman hijau. Berdasarkan hasil pengolahan citra garis pantai mengalami perubahan akibat abrasi. Kemunduran garis pantai terjadi di setiap tahunnya. Menurut Bapak Hadi (pedagang), abrasi terjadi sejauh 50 meter selama tiga tahun terakhir. Desa Penyaringan mempunyai wilayah yang luas dengan pantai sebagai batas desa bagian selatan. Dari olahan data citra, garis pantai tahun 2014 dan 2015 terlihat mengalami abrasi Berdasarkan informasi dari Bapak Gede Tiarta diketahui bahwa garis pantai di Desa Penyaringan mengalami abrasi sejauh 50 meter. Pengolahan data citra satelit landsat 8 menunjukkan Desa Yehembang Kangin mengalami perubahan garis pantai dari tahun 2013 hingga 2016. Dari hasil wawancara dengan Bapak Wayan Tarma, garis pantai di Desa Yehembang Kangin tidak mengalami perubahan.

Selanjutnya di Desa Yehembang, perubahan garis pantai yang ditunjukkan oleh pengolahan data citra satelit terjadi setiap tahun. Abrasi cukup jauh terjadi di tahun 2015. Dari Bapak Nengah Wirana diketahui garis pantai di desa ini mengalami perubahan sejauh 200 meter dalam kurun waktu 5 tahun terakhir Pantai di Desa Yehembang dimanfaatkan sebagai tempat mencari ikan. Sebagian warganya bekerja sebagai Nelayan. Pada pesisir pantai Desa Yeh Sumbul terdapat bangunan vila. Tidak jauh dari pantai juga terdapat tanaman hijau serta sawah. Pantai ini juga merupakan pantai wisata di kecamatan Mendoyo. Tahun 2015 mengalami kemunduran sedangkan tahun 2016 kembali mengalami penambahan daratan.

\section{Kecamatan Pekutatan}

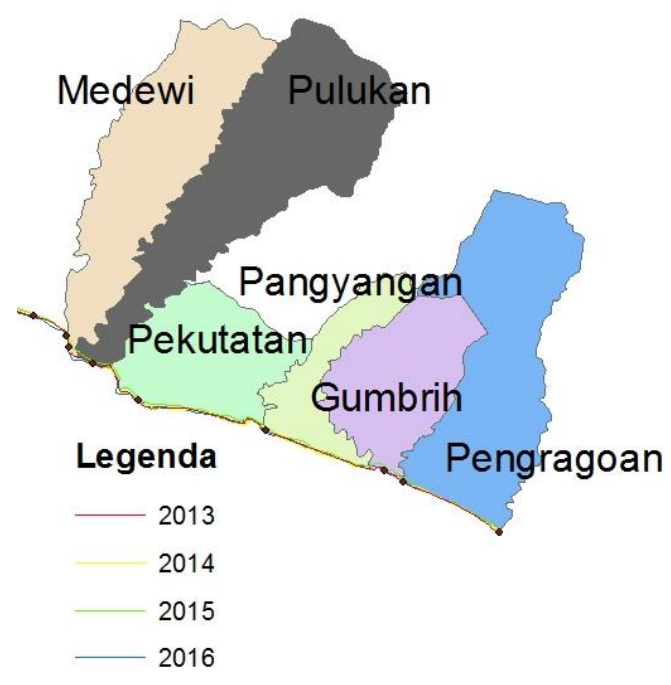

GAMBAR 7. Desa Pesisir di Kecamatan Pekutatan.

Pantai Medewi terkenal dengan keindahan pantai berbatu. Di pesisir pantai terdapat bangunan hotel dan restaurant Dari pengolahan citra landsat, terlihat bahwa tahun 2014 terjadi penambahan daratan di beberapa titik. Tahun 2015 hampir sepanjang pantai medewi mengalami kemunduran atau abrasi. Desa Pulukan memiliki wilayah pantai yang relatif kecil. Pengolahan citra menujukkan perubahan garis pantai yang dinamis di daerah ini, sehingga garis pantai di desa Pulukan cenderung tidak mengalami perubahan. Pantai Pekutatan merupakan pantai berbatu. Pantai ini menjadi salah satu destinasi wisata di Jembrana. Terdapat bangunan hotel dan penginapan di pesisir pantai. Data citra menunjukkan adanya perubahan garis pantai akibat abrasi di tahun 2014.

Pantai Pangyangan mengalami perubahan garis pantai akibat abrasi. Pada tahun 2015 dibangun batuan penahan gelombang. Sebelumnya, jika pasang purnama, air laut bisa mencapai jalan. Desa Gumbrih memiliki wilayah pantai yang relatif pendek. Terdapat banyak sampah di 
pantai Desa Gumbrih. Selain itu, terdapat tanaman hijau di pinggir pantai. Pengolahan data citra memperlihatkan tahun 2015 terjadi abrasi di beberapa titik. Pada tahun 2016 terjadi pula perubahan akibat abrasi namun tidak signifikan. Desa Pengragoan berada di sebelah timur jembrana berbatasan dengan kabupaten tabanan. Pantai di desa ini tergolong pada tipe pantai berbatu. Dilihat dari pengolahan citra, terjadi perubahan garis pantai tiap tahun. Dari data wawancara dengan bapak Made Suartana, diperoleh informasi bahwa dulunya terdapat pohon di pesisir pantai. Namun saat ini air laut sudah mendekati jalan. Terjadi abrasi sekitar 20 meter selama 2 tahun terakhir.

\section{Luas Perubahan Garis Pantai Kabupaten Jembrana}

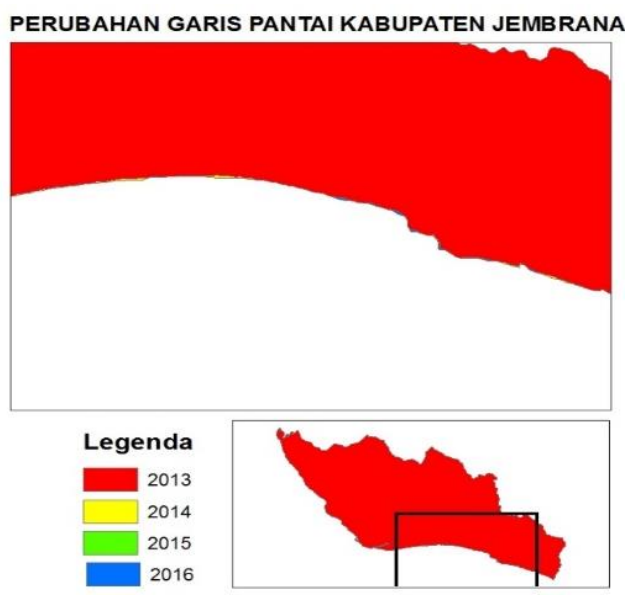

GAMBAR 8. Perubahan Garis Pantai Kabupaten Jembrana

Berdasarkan hasil analisis citra, diperoleh informasi luasan perubahan garis pantai di kabupaten Jembrana sebagai berikut.

TABEL 1. Data Luas Perubahan Garis Pantai

\begin{tabular}{cccc}
\hline No. & Tahun & Abrasi $\left(\mathbf{m}^{\mathbf{2}}\right)$ & Akresi $\left(\mathbf{m}^{\mathbf{2}}\right)$ \\
\hline 1. & $2013-2014$ & 801.717 & 1348.564 \\
2. & $2014-2015$ & 4921.561 & 388.969 \\
3. & $2015-2016$ & 348.637 & 4431.331 \\
\hline
\end{tabular}

\section{KESIMPULAN}

Berdasarkan hasil penelitian yang telah dilakukan, dapat disimpulkan beberapa hal sebagai berikut:

1. Perubahan garis pantai dapat diketahui dengan mengolah data citra satelit. Perubahan pantai terjadi di setiap titik pengamatan lapangan.

2. Abrasi terbesar terjadi di tahun 2014-2015 yaitu $4921.561 \mathrm{~m}^{2}$ sedangkan akresi terbesar terjadi di tahun 2015-2016 yaitu $4431.331 \mathrm{~m}^{2}$.

\section{REFERENSI}

[1] Fandeli C. 2011. “Analisis Mengenali Dampak Lingkungan Pembangunan Pelabuhan.” Yogyakarta: UGM-Press. 211 hal.

[2] Lillesand T.M. dan R.W. Kiefer, 1987. “Remote Sensing and Image Interpretation,” John Willey and Sons, Inc.

[3] Sutanto, 1986. "Penginderaan Jauh Jilid I.” Gadjah Mada University Press. Bulaksumur, Yogyakarta. 
[4] Triatmodjo, B. 1999. “Teknik Pantai.” Beta Offset. Yogyakarta.

[5] Wibisono, M. S. 2005. "Pengantar Ilmu Kelautan.” PT. Gramedia WIdiasarana Indonesia. Jakarta. 